\title{
QUEEN'S
UNIVERSITY
BELFAST
}

\section{Inter-laboratory assessment by trained panelists from France and the United Kingdom of beef cooked at two different end-point temperatures}

Gagaoua, M., Micol, D., Picard, B., Terlouw, C. E. M., Moloney, A. P., Juin, H., Meteau, K., Scollan, N., Richardson, I., \& Hocquette, J-F. (2016). Inter-laboratory assessment by trained panelists from France and the United Kingdom of beef cooked at two different end-point temperatures. Meat Science, 122, 90-96.

https://doi.org/10.1016/j.meatsci.2016.07.026

\section{Published in:}

Meat Science

\section{Document Version:}

Peer reviewed version

Queen's University Belfast - Research Portal:

Link to publication record in Queen's University Belfast Research Portal

\author{
Publisher rights \\ (C) 2016 Elsevier Ltd. \\ This manuscript version is made available under the CC-BY-NC-ND 4.0 license http://creativecommons.org/licenses/by-nc-nd/4.0/,which \\ permits distribution and reproduction for noncommercial purposes, provided the author and source are cited.
}

\section{General rights}

Copyright for the publications made accessible via the Queen's University Belfast Research Portal is retained by the author(s) and / or other copyright owners and it is a condition of accessing these publications that users recognise and abide by the legal requirements associated with these rights.

Take down policy

The Research Portal is Queen's institutional repository that provides access to Queen's research output. Every effort has been made to ensure that content in the Research Portal does not infringe any person's rights, or applicable UK laws. If you discover content in the

Research Portal that you believe breaches copyright or violates any law, please contact openaccess@qub.ac.uk. 


\section{Accepted Manuscript}

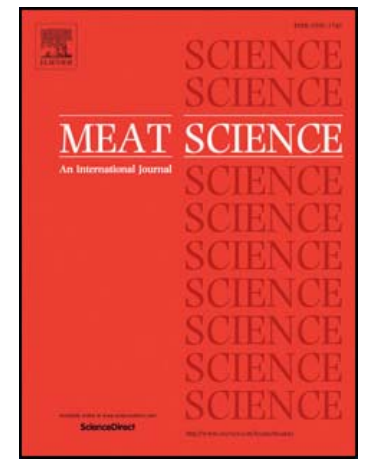

Inter-laboratory assessment by trained panelists from France and the United Kingdom of beef cooked at two different end-point temperatures

Mohammed Gagaoua, Didier Micol, Brigitte Picard, Claudia E.M. Terlouw, Aidan P. Moloney, Hervé Juin, Karine Meteau, Nigel Scollan, Ian Richardson, Jean-François Hocquette

PII:

S0309-1740(16)30245-5

DOI:

doi: 10.1016/j.meatsci.2016.07.026

Reference:

MESC 7074

To appear in: $\quad$ Meat Science

Received date: 26 January 2016

Revised date: $\quad 28$ July 2016

Accepted date: $\quad 29$ July 2016

Please cite this article as: Gagaoua, M., Micol, D., Picard, B., Terlouw, C.E.M., Moloney, A.P., Juin, H., Meteau, K., Scollan, N., Richardson, I. \& Hocquette, J.-F., Inter-laboratory assessment by trained panelists from France and the United Kingdom of beef cooked at two different end-point temperatures, Meat Science (2016), doi: 10.1016/j.meatsci.2016.07.026

This is a PDF file of an unedited manuscript that has been accepted for publication. As a service to our customers we are providing this early version of the manuscript. The manuscript will undergo copyediting, typesetting, and review of the resulting proof before it is published in its final form. Please note that during the production process errors may be discovered which could affect the content, and all legal disclaimers that apply to the journal pertain. 


\title{
Inter-laboratory assessment by trained panelists from France and the United Kingdom of beef cooked at two different end-point temperatures
}

\author{
Mohammed Gagaoua ${ }^{1,2,3}$, Didier Micol ${ }^{1,2(\#)}$, Brigitte Picard ${ }^{1,2}$, Claudia E.M. Terlouw ${ }^{1,2}$, \\ Aidan P. Moloney ${ }^{4}$, Hervé Juin ${ }^{5}$, Karine Meteau ${ }^{5}$, Nigel Scollan ${ }^{6}$, Ian Richardson ${ }^{7}$, \\ Jean-François Hocquette ${ }^{1,2(*)}$
}

${ }^{1}$ INRA, UMRH 1213, Unité de Recherches sur les Herbivores, Theix, 63122 Saint Genès Champanelle, France

2 VetAgro Sup, UMRH 1213, Unité de Recherches sur les Herbivores, Theix, 63122 Saint Genès Champanelle, France

${ }^{3}$ Equipe Maquav, INATAA, Université Frères Mentouri Constantine, Route de Ain El-Bey, 25000 Constantine, Algeria

${ }^{4}$ Teagasc, Animal and Grassland Research and Innovation Centre, Grange, Dunsany, Co. Meath, Ireland

${ }^{5}$ INRA, UE1206, Elevage Alternatif et Santé Animale, Le Magneraud, F-17700 Saint Pierre d'Amilly, France

6 Institute of Biological, Environmental and Rural Sciences, Aberystwyth University, Gogerddan, SY23 3EB, UK

${ }^{7}$ Division of Farm Animal Science, University of Bristol, Langford, Bristol, BS40 5DU, UK

(\#) Deceased. We would like to dedicate this work to the memory of Didier Micol.

(*) Correspondence: Jean-François Hocquette: jean-francois.hocquette@ clermont.inra.fr

\begin{abstract}
Eating quality of the same meat samples from different animal types cooked at two endpoint cooking temperatures $\left(55^{\circ} \mathrm{C}\right.$ and $\left.74^{\circ} \mathrm{C}\right)$ was evaluated by trained panels in France and the United Kingdom. Tenderness and juiciness scores were greater at 55 than $74^{\circ} \mathrm{C}$, irrespective of the animal type and location of the panel. The UK panel, independently of animal type, gave greater scores for beef flavour $(+7$ to $+24 \%, P<0.001)$ but lower scores for abnormal flavour $(-10$ to $-17 \%, P<0.001)$ at $74^{\circ} \mathrm{C}$. Abnormal flavour score by the French panel was higher at $74^{\circ} \mathrm{C}$ than at $55^{\circ} \mathrm{C}(+26 \%, P<0.001)$. Irrespective of the data set, tenderness was correlated with juiciness and beef flavour. Overall, this study found that cooking beef at a lower temperature increased tenderness and juiciness, irrespective of the location of the panel. In contrast, cooking beef at higher temperatures increased beef flavour and decreased abnormal flavour for the UK panellists but increased abnormal flavour for the French panel.
\end{abstract}

Key words: Beef; meat sensory qualities; end-point cooking temperature; sensory protocol. 


\section{Introduction}

Eating quality is one of the most important characteristics by which consumers assess beef (Grunert, Bredahl \& Brunsø, 2004). Although factors such as the amount of visual fat and the colour of the meat or extrinsic factors such as price, brand, etc. (reviewed by Hocquette et al. (2012)) influence purchase, aspects of the meat such as taste and tenderness play an important role in the decision to re-purchase after consumption of the meat (Grunert et al., 2004; Monson, Sanudo \& Sierra, 2005). Meat acceptability and the individual preferences of consumers depend on the individual sensory responses during meat consumption, including perception of tenderness, juiciness, and flavour (Gagaoua, Micol, Richardson et al., 2013; Jeremiah \& Gibson, 2003). Of the sensory traits of beef meat, it is generally believed that tenderness is the most important sensory (Huffman et al., 1996; Legrand, Hocquette, Polkinghorne \& Pethick, 2013). Various studies indicate that consumers are willing to pay a premium for beef meat provided if it is guaranteed to be tender (Boleman et al., 1997; Miller Carr, Ramsey, Crockett \& Hoover, 2001; Platter et al., 2005).

Despite considerable efforts to improve beef eating quality, research has shown that there can still be a high level of uncontrolled variability in beef tenderness (Maher, Mullen, Moloney, Buckley \& Kerry, 2004). This may be the reason why consumers would like a system to predict beef eating quality, which is adequate, simple, sufficiently documented and controlled by an independent third party (Verbeke et al., 2010). Eating quality is influenced by both genetic and environmental factors including genotype, age, and diet, as well as preslaughtering management and post-mortem processing conditions. In addition, cooking is the final step applied prior to consumption and gives meat its final characteristics and is, therefore, another important factor (Obuz \& Dikeman, 2003). Meat preferences of members of taste panel depends upon their previous cultural experiences and eating habits (Dransfield et al., 1984; Grunert et al., 2004; Oliver et al., 2006) though this should not affect their ability to respond to differences in tenderness, juiciness or flavour (Sanudo et al., 1998).

The objective of this study was to compare beef eating quality scores of samples of the same meat cooked to two different end-point temperatures $\left(55^{\circ} \mathrm{C}\right.$ or $\left.74^{\circ} \mathrm{C}\right)$ and assessed by sensory panels in France and the United Kingdom which differed in their protocols and sensory scales. The results allowed an evaluation of the effect of end-point cooking temperature on beef sensory traits determined by trained panels. These data will increase our understanding of the relationships among meat sensory attributes according to cooking temperature. 


\section{Materials and methods}

Animal management followed the European Union directive number 86/609/EEC concerning animal care.

\subsection{Animals and diets}

This study was conducted as part of the European "ProSafeBeef" project (www.prosafebeef.eu). The overall aim of "ProSafeBeef" was to improve safety and quality in beef production and processing, across Europe through research and innovation. It was based on 240 cattle including young bulls, steers and heifers reared in three European experimental research centres, France, UK and Ireland, respectively (Table 1) as recently reported by (Gagaoua et al., 2016). The experiment in France involved 74 young bulls of 3 different breeds: Limousin (Li), Blond d'Aquitaine (BA) and Aberdeen Angus (AA). The experiment in Ireland involved 96 heifer calves of two genotypes, Belgian-Blue x Holstein-Friesian (BF) and Aberdeen Angus x Holstein-Friesian (AF). The experiment in UK involved 72 steers half of which were Belgian-Blue $x$ Holstein $(\mathrm{BH})$ and the other half Charolais $x$ Friesian $(\mathrm{CF})$. During the finishing period, in the three experimental farms, the animals were kept in either extensive (grazing) or intensive conditions (indoors) (Gagaoua et al., 2013). Basal diets offered to the animals consisted of pasture, grass silage or high concentrate diets, and were supplemented with lipids and/or antioxidants from plants additives.

\subsection{Slaughtering and sampling}

Animals were slaughtered when they achieved fat class 3 on the EUROP grid of carcass classification (European Economic Community Regulations (EEC) No. 1208/81). They were slaughtered under standard conditions in either a commercial or an experimental slaughterhouse, depending on the facilities of each country. The carcasses were not electrically stimulated and they were chilled and stored at $4^{\circ} \mathrm{C}$ until $24 \mathrm{~h}$ post-mortem. The Longissimus thoracis (LT) muscle was excised from the right side of each carcass $24 \mathrm{~h}$ after slaughter. The samples were cut into steaks (5 $\mathrm{cm}$ thick) and placed in 80 -micron sealed plastic bags (40 nylon/60 polyethylene with permeability specifications of $50 \mathrm{~cm}^{3} \mathrm{O}_{2} / \mathrm{m}^{2} / \mathrm{d}, 10 \mathrm{~cm}^{3} \mathrm{~N}_{2} / \mathrm{m}^{2} / \mathrm{d}$, $150 \mathrm{~cm}^{3} \mathrm{CO}_{2} / \mathrm{m}^{2} / \mathrm{d}$ and $2.4 \mathrm{~g} \mathrm{H}_{2} \mathrm{O} / \mathrm{d}$ at $23{ }^{\circ} \mathrm{C}$ and $75 \% \mathrm{RH}$ (Terinex, Bedford, England)) under Multivac A300/42 vacuum packager (Multivac UK, Swindon, UK) to -980 mbar and kept between $2-4^{\circ} \mathrm{C}$ for 14 days (young bulls from France and heifers from Ireland) or 10 days 
(steers from UK) for ageing. Each loin sample was then frozen and stored at $-20^{\circ} \mathrm{C}$ until sensory assessment.

\subsection{Sensory panels}

Sensory assessment was conducted in two dedicated laboratories in the UK and France. In both laboratories, the expert panelists used were trained in accordance with the ISO standards ISO/TC 34 (ISO_8586, 2012). Briefly, the sensory panelists were selected based on their sensory sensitivity, appropriate training and experience in sensory testing. Formal evaluation allowed selection of those panelists capable of making consistent and repeatable sensory assessments of meat products that is, making comparative judgements both within a session and from one session to another. The continuous accuracy and precision of these panelists has been assured in both countries by regular training sessions and subsequent evaluation of performance, according to the ISO 8588-1 standards. For the present study, both laboratories used panelists with several years experience of sensory evaluation of meat and meat products.

For sensory evaluation, meat samples from the young bulls (France) were assessed for sensory scores in France (INRA, Le Magneraud). Meat samples from the heifers (Ireland), the steers (UK) and the young bulls (France) were assessed for sensory scores in the UK (University of Bristol) (Table 1). Meat samples from France and Ireland were transported to the UK while maintained at $-20^{\circ} \mathrm{C}$ and were clearly and appropriately labelled. The descriptors used in the sensory evaluation of beef meat by the two trained sensory panels are given in Table 2. Within each sensory protocol, scores were averaged across panelists for each steak, and the means were used in the statistical analyses.

\subsubsection{The French sensory protocol}

Steaks were thawed, without stacking or overlapping, at 2 to $5{ }^{\circ} \mathrm{C}$ in vacuum packs for at least $24 \mathrm{~h}$ or $48 \mathrm{~h}$ before cooking and sensory assessment at $55{ }^{\circ} \mathrm{C}$ or $74{ }^{\circ} \mathrm{C}$. One hour before sensory assessment, the meat samples were cut into four approximately $1.50 \mathrm{~cm}$ thick steaks, 2 steaks to be assigned for cooking to $55^{\circ} \mathrm{C}$ and 2 steaks for cooking to $74^{\circ} \mathrm{C}$. After exposure to air for $1 \mathrm{~h}$ at $18^{\circ} \mathrm{C}$, the steaks were grilled on a double grooved plate griddle (SOFRACA, Morangis, France) heated to $310^{\circ} \mathrm{C}$ for $30 \mathrm{~min}$ before cooking. Steaks were heated for $2 \mathrm{~min}$ between two aluminium foil sheets, until the end-points temperature of $55^{\circ} \mathrm{C}$ or $74^{\circ} \mathrm{C}$ in the geometric centre of the steak was reached (measured using a temperature probe (Type K, HANNA HI 98704, Newark, USA)). After grilling, each steak was cut into twelve $3 \times 2 \times 1.5$ 
$\mathrm{cm}$ portions which were immediately presented to 12 panelists (one portion per panelist). The panelists rated the steaks on a $10 \mathrm{~cm}$ unstructured line scale (from 0 to 10 ) measured in $\mathrm{mm}$ for the following attributes: global tenderness (0 - extremely tough, 10 - extremely tender), juiciness $(0$ - extremely dry, 10 - extremely juicy), beef flavour intensity ( 0 - extremely weak, 10 - extremely strong) and abnormal flavour intensity ( 0 - extremely weak, 10 - extremely strong). The sessions were carried out in a sensory analysis room equipped with individual booths under artificial red light to reduce the influence of the appearance of the samples. Each session comprised of 6 samples from a single breed. Sessions were organized in a balanced design for panelists and order of testing. Each tasting booth was equipped with computer terminals linked to a fileserver running a sensory software programme (Fizz v 2.20h, Biosystemes, Couternon, France) that facilitated the direct entry of assessor ratings, which were formatted in Excel.

\subsubsection{The UK sensory protocol}

The samples, by breed for each animal type were defrosted overnight at $4{ }^{\circ} \mathrm{C}$ and then cut into $2.0 \mathrm{~cm}$ thick steaks. The steaks are then grilled under the overhead heat from grill elements of a Tricity double oven domestic cooker producing approximately $120^{\circ} \mathrm{C}$ at the meat surface; turning every two minutes until reaching the internal temperatures of 55 or $74^{\circ} \mathrm{C}$ in the geometric centre of the steak (measured by a thermocouple probe). After grilling, all fat and connective tissue was trimmed and each steak was cut into $3 \times 2 \times 2 \mathrm{~cm}$ blocks. The blocks were wrapped in pre-labelled foil, placed in a heated incubator at $55{ }^{\circ} \mathrm{C}$ for no more than 15 minutes before testing by 10 panelists, trained in beef meat sensory analysis, in a balanced order (Macfie, Bratchell, Greenhoff \& Vallis, 1989). The sensory evaluation was conducted in individual booths illuminated with red light and equipped with a sensory software programme (FIZZ v 2.20h, Biosystemes, Couternon, France) that facilitated the direct entry of assessor ratings. The assessors used 8-point category scales to evaluate the following traits: tenderness $(0$ - extremely tough, 8 - extremely tender), juiciness ( 0 - extremely dry, 8 - extremely juicy), beef flavour intensity ( 0 - extremely weak, 8 - extremely strong) and abnormal flavour intensity $(0$ - extremely weak, 8 - extremely strong).

\subsection{Statistical analysis}

Variance analyses were carried out using PROC GLM of SAS (SAS Version 9.1. SAS institute Inc., Cary, NC, USA) separately for each animal type to test the effect of cooking 
temperature (Table 1). Least square means separation was carried out using the Tukey test and differences were considered significant at $P<0.05$.

To study relationships between meat sensory scores, Z-scores were calculated for each temperature to remove animal type (gender and breed) and country effects. Z-scores represent the deviation of each observation relative to the mean of the corresponding animal type in each country and were calculated using PROC STANDARD of SAS, which standardizes data to a mean of 0 and standard deviation of 1 . More precisely, the standard score of a raw score $x$ was calculated using the following formula: $z=\frac{x-\mu}{\sigma}$ where: $\mu$ is the mean animal type and $\sigma$ is the standard deviation of each corresponding animal type (Gagaoua, Terlouw, Boudjellal, \& Picard, 2015a).

The PROC CORR of SAS was used to determine the Pearson's correlation coefficients between the attributes. Correlation coefficients were considered significant at $P<0.05$.

Principal component analyses (PCA) were carried out to visually illustrate the effects of temperature on the distribution of the sensory attributes for all animal types (assessed by the UK sensory protocol) and for young bulls (assessed by the French protocol). The PCA's were based on partial datasets of the Z-scores calculated per animal type, sensory protocol and endpoint cooking temperatures using PROC PRINCOMP of SAS. The Kaiser-Meyer-Olkin (KMO) measure, known also as Kaiser's Measure of Sampling Adequacy (MSA) was applied to test the validity of the sampling (Gagaoua et al., 2015b). The overall MSAs were computed using PROC FACTOR of SAS and are given for each PCA.

\section{Results}

\subsection{Effect of end-point cooking temperature on sensory attributes}

Sensory analyses carried out in the UK using a $0-8$ category scale (Table 3) showed that for all animal types (young bulls, steers and heifers), tenderness, juiciness and abnormal flavour scores were greater $(P<0.001)$ at 55 than at $74^{\circ} \mathrm{C}$, ranging between +10 to $+29 \%$. In contrast, beef flavour score was lower $(P<0.001)$ after cooking at $55^{\circ} \mathrm{C}$ than at $74^{\circ} \mathrm{C}$ : $-24 \%$ for young bulls, $-14 \%$ for steers and $-7 \%$ for heifers.

For samples from young bulls evaluated by the French panel, using a 0 - 10 scale (Table 4), tenderness and juiciness scores were greater $(+12$, and $+23 \%$ respectively, $P<0.001)$ at $55^{\circ} \mathrm{C}$ 
than at $74^{\circ} \mathrm{C}$, similar to that noted by the UK panel. However, abnormal flavour score was higher at $74^{\circ} \mathrm{C}$ than at $55^{\circ} \mathrm{C}(+26 \%, P<0.001)$ and no difference was observed for beef flavour scores at the two temperatures.

\subsection{Relationships between sensory attributes}

Consistent correlations in partial datasets of the Z-scores (all animal types) were found between the different sensory attributes at the two cooking end-point temperatures for the samples assessed in the UK (Table 5). Tenderness and juiciness were positively correlated $(P$ $<0.001 ; \mathrm{r}=0.33$ vs. 0.42 ; at 55 and $74^{\circ} \mathrm{C}$, respectively). Tenderness was positively correlated with beef flavour at both temperatures $\left(P<0.05 ; \mathrm{r}=0.15 v s .0 .29\right.$; at $55^{\circ} \mathrm{C}$ and $74^{\circ} \mathrm{C}$, respectively) and negatively correlated $(P<0.05 ; \mathrm{r}=-0.15)$ with abnormal beef flavour at $55^{\circ} \mathrm{C}$ only. Beef flavour was negatively correlated with abnormal beef flavour $(P<0.001$; $\mathrm{r}=-$ 0.62 and -0.56 , at $55^{\circ} \mathrm{C}$ and $74^{\circ} \mathrm{C}$, respectively) and was positively correlated $(P<0.05)$ with juiciness at $74^{\circ} \mathrm{C}$.

Similarly, when the dataset of the young bulls assessed by the French protocol were considered, consistent correlations were found between the different sensory attributes (Table 6). Some correlations were similar to those found for the complete UK data set. At both 55 and $74^{\circ} \mathrm{C}$, tenderness was positively correlated with juiciness $(P<0.001 ; \mathrm{r}=0.40$ and $\mathrm{r}=0.65$, respectively) and beef flavour $(P<0.001 ; \mathrm{r}=0.40$ and $\mathrm{r}=0.50$, respectively). In addition, at both temperatures, juiciness was correlated with beef flavour $(P<0.01 ; \mathrm{r}=0.23 v s .0 .49$; at 55 and $74^{\circ} \mathrm{C}$, respectively). Beef flavour was negatively correlated $(P<0.05)$ with abnormal beef flavour at $74^{\circ} \mathrm{C}$ only.

Relationships between sensory scores were visualized using PCA. When the PCA was computed using the UK sensory ratings for samples of all animal types (Figure 1), $53.5 \%$ of the variability was explained with the first two axes with an overall MSA of 0.72 . The first principal component which explained $33.4 \%$ of the variability was mainly characterized by global tenderness, juiciness and beef flavour on the right side, and abnormal flavour on the left side showing that abnormal flavour was negatively associated with beef flavour, juiciness and global tenderness. Apart from juiciness at $74^{\circ} \mathrm{C}$, all attributes scored over 0.5 on the first principal component. The PCA also shows the relationship between sensory attributes grouped by batches as illustrated by circles on the graph. 
The PCA computed using the French sensory ratings for the samples of young bulls only (Figure 2) explained 53.6\% of the variability with an overall MSA of 0.74 . As for the UK data set, the first axis showed the negative relationship between abnormal flavour on one side and beef flavour, juiciness and global tenderness on the other side. The second axis allowed a significant discrimination of the evaluated attributes according to cooking temperature. Tenderness, juiciness and beef flavour assessed at $55^{\circ} \mathrm{C}$ were grouped together on the top right side of the first axis and the same attributes assessed at $74^{\circ} \mathrm{C}$ on the bottom right side. The projection of these attributes together reflects the positive correlations between them. In addition, the PCA in Figure 2 illustrates the effects of end-point cooking temperatures on the preferences of the French panel. Tenderness was associated with juiciness and beef flavour at both temperatures.

\section{Discussion}

Understanding consumer perception of beef meat attributes, such as tenderness, juiciness and beef flavours is of great importance for the meat industry but, as shown in this study using common beef samples, these attributes differ according to cooking temperatures.

\subsection{Effect of end-point cooking temperature on tenderness and juiciness}

The results clearly showed that tenderness and juiciness scores were lower at the higher internal end-point cooking temperature, irrespective of animal type and sensory protocol used. This may be related to the physical-chemical changes that occurred to the meat during the cooking period. The increase in internal end-point temperature may be related to higher water loss during cooking, with a direct influence on the texture attributes (both juiciness and tenderness) and flavour of the steak (discussed below).

The findings for tenderness are in agreement with numerous studies reporting greater tenderness (or lower toughness) when meat is cooked at lower temperatures $\left(<60^{\circ} \mathrm{C}\right)$ (Bejerholm, Tørngren \& Aaslyng, 2014; Cross, Stanfield \& Koch, 1976; Gomes, Pflanzer, de Felício \& Bolini, 2014; Joseph, Awosanya, Adeniran \& Otagba, 1997; Mortensen, Frøst, Skibsted \& Risbo, 2012; Tornberg, 2005). For example, Lorenzen, Davuluri, Adhikari \& Grün (2005) reported that acceptability of tenderness decreased as end-point temperature increased from 55 to $82^{\circ} \mathrm{C}$. 
An earlier study by Wood, Nute, Fursey \& Cuthbertson (1995) showed that increasing the end-point cooking temperature of pork from 65 to 72.5 or $80^{\circ} \mathrm{C}$, decreased tenderness, juiciness and abnormal flavour, but increased flavour. Similarly, in another study, Lorenzen et al. (2003) found that shear values for top sirloin steaks increased with increasing endpoint temperature. Indeed, cooking is believed to have a marked effect on meat tenderness due to modification of both the connective and the myofibrillar structures (actin and myosin) as a result of thermal transitions (Bejerholm et al., 2014; Dubost et al., 2013; Martens, Stabursvik \& Martens, 1982; Purslow, 2014). According to Christensen, Purslow \& Larsen (2000) and McCormick (2009), meat tenderness decreases in two distinct phases, the first from 40 to $50^{\circ} \mathrm{C}$ and the second from 60 to $80^{\circ} \mathrm{C}$ with a significant increase between 50 and $60^{\circ} \mathrm{C}$. Furthermore, Tornberg (2005) and Wulf, Morgan, Tatum \& Smith (1996) reported that collagen solubilisation occurs when temperature is increased above $55^{\circ} \mathrm{C}$ and Tornberg (2005) also hypothesized that above $65^{\circ} \mathrm{C}$, elasticity increases, reducing tenderness. In addition, intramuscular collagen is known to undergo shrinkage near $60-65^{\circ} \mathrm{C}$ (Bailey \& Light, 1989). Hence, we can speculate that irrespective of animal type, cooking meat above $55^{\circ} \mathrm{C}$ reduces tenderness due to increased elasticity, despite solubilisation of collagen.

The greater juiciness scores at $55^{\circ} \mathrm{C}$ than at $74^{\circ} \mathrm{C}$ were also reported in the previously cited studies and by many others (Bowers, Dikeman, Murray \& Stroda, 2012; Gomes, Pflanzer, Cruz, de Felício \& Bolini, 2014; Martens et al., 1982). For example, beef cooked to a rare endpoint temperature $\left(<60^{\circ} \mathrm{C}\right)$ tends to be more tender and juicy than meat cooked to a well-done endpoint $\left(>70^{\circ} \mathrm{C}\right)$ (Bowers, Craig, Kropf \& Tucker, 1987; Obuz \& Dikeman, 2003). Meat juiciness plays a key role in meat texture and refers to the mouthfeel of the moisture released during mastication. Thus, juiciness is indicative of the moisture released from meat during chewing and from saliva in response to lipid stimulation (Savell et al., 1989). It was recently suggested that water acts as a plasticizer of muscle proteins and its loss influences structural properties by increasing the stiffness and hardness of the cooked meat (Hughes, Oiseth, Purslow \& Warner, 2014). Water is lost from the myofibrillar lattice structure as a result of protein denaturation and contraction of muscle structures by increasing cooking temperature. In addition, Aaslyng, Meinert, Bejerholm \& Warner (2014) postulated that the major loss of juiciness is as a result of actin denaturation. Martens et al. (1982) proposed the possibility of the thermally induced protein-protein aggregation of actin in the myofibrils expelling water from the myofibril, either by reducing the water-binding capacity of the native gel-like 
structure in the myofibril, or by contraction of the myofibrils, resulting from the formation of new aggregation cross links.

\subsection{Effect of end-point cooking temperature on beef and abnormal beefflavours}

The effect of cooking temperature on beef flavour and abnormal flavour was less pronounced than on tenderness and juiciness and depended on the country of the panel. Beef flavour is an important component of the overall acceptability of meat. It is a complex sensory attribute, influenced by a variety of factors and much research has focused on understanding its chemistry (Mottram, 1998). It can be influenced by compounds that stimulate the olfactory organ, as well as those influencing the sense of taste (Mottram, 1998). Further, its perception may be also influenced by mouthfeel, juiciness, texture and temperature sensations (Pegg \& Shahidi, 2004). The effect on temperature sensation of the interaction between temperature and volatile components depends on the range of end-point temperatures used and the nature of the protein (Mottram, 1998). The data from the UK protocol in the present study are in agreement with various studies that show higher beef flavour scores when meat is cooked well done (temperatures $>70^{\circ} \mathrm{C}$ ) compared to very rare or rare (temperatures $<60^{\circ} \mathrm{C}$ ) (Cross et al., 1976; Savell et al., 1999). The lower beef flavour scores in meat grilled at the lower temperature are in agreement with the strong contribution of volatile compounds generated at high temperatures to meat flavour (Mottram, 1998). Despite this, Bowers et al, (1987) found the highest flavour scores at lower $\left(55-60^{\circ} \mathrm{C}\right)$ cooking temperatures. One explanation for this result is that beef flavour may have been masked by the presence of other flavour components, for instance abnormal beef flavour, which in our study was higher after cooking at lower temperatures for the UK protocol (Lawless \& Heymann, 2010). For the French protocol, no difference was found between end-point temperatures for beef flavour. This may be due to the relatively greater importance of texture (tenderness and juiciness) for French panel (the scores are 1.2 fold higher) compared to flavour. In addition, flavour may be slightly affected by cooking temperature for certain consumers as previously reported (Christensen et al., 2012).

The effect of temperature on abnormal beef flavour depended on the country of the panel. Abnormal flavour can occur because of the original meat composition (high iron content for example) or because of changes that occur during processing (rate and extent of $\mathrm{pH}$ values), cooking, or storage. The latter depends on the amount of lipids and fatty acids and/or their quality. For example, if muscle glycogen concentration is reduced by pre-slaughter stress, the intensity of abnormal or off-flavours is increased (Young, Reid \& Scales, 1993) and the 
elevated $\mathrm{pH}$ may also influence abnormal flavour development. Studies on meat products suggest that fat acts as a solvent for volatile compounds, thus delaying flavour release or its development (Elmore \& Mottram, 2009). Further, we think that negative effects involve rancidity due to peroxidation of polyunsatured fatty acids and the development of rancid flavour, potentially resulting in a loss of desirable flavour compounds.

Overall, contrary to the results relative to meat texture, cooking beef at a higher temperature was an advantage in terms of beef and abnormal flavour for the UK protocol and a disadvantage in terms of abnormal beef flavour for the French protocol. These differences may be partly explained by the different habits and preferences of the panelists in each country. In addition, another phenomenon known as the "halo effect" may explain these differences. For example, increased juiciness increases the perception of tenderness and vice versa (Gill et al., 2010; Jenkins et al., 2011). This may also explain the correlations observed between tenderness and juiciness, which were stronger for the French panel compared to the UK panel.

\subsection{Relationships between sensory attributes}

Consistent correlations were found between the different sensory attributes at the two endpoint cooking temperatures for both sensory panels. Independent from animal type, end-point temperature and sensory protocol, tenderness was correlated with juiciness and beef flavour. These findings are consistent with numerous recently published reports (O'Quinn et al., 2012; Hunt et al., 2014; Corbin et al., 2015) and are consistent with their role in meat quality acceptance. It has been reported that the most important attributes that influence acceptability are tenderness and juiciness (Butler, Poste, Mackie \& Jones, 1996; Zimoch \& Gullett, 1997) and to a lesser degree flavour (Font-i-Furnols \& Guerrero, 2014). The relationship with beef flavour may be partly related to the role of intramuscular fat since tenderness and juiciness were reported to be both positively correlated with intramuscular fat content (O'Quinn et al., 2012; Pannier et al., 2014).

Other sensory studies showed that there is also a strong positive correlation between meat tenderness and juiciness in different muscles. For example, Otremba et al. (2000) reported a correlation coefficient of 0.69 between juiciness and tenderness for beef Longissimus and Semitendinosus muscles. In another study, Shackelford, Wheeler \& Koohmaraie (1995) reported correlation coefficients in the range of 0.14 (Psoas major) to 0.76 (Triceps brachii) for ten beef muscles. 
Irrespective of animal type, juiciness was not correlated with beef flavour as assessed by the UK sensory protocol at the end-point cooking temperature of $74^{\circ} \mathrm{C}$. In contrast, with the French sensory protocol, significant correlations were observed at both cooking temperatures. Recent studies by Corbin et al. (2015) and O'Quinn et al. (2012) show similar findings to the latter. Except for one data set (the French protocol with beef from young bulls cooked at $55^{\circ} \mathrm{C}$ ), normal and abnormal beef flavour were negatively correlated. Similar findings were reported in other studies with beef (Campo et al., 2006; Gill et al., 2010) and lamb (Karamichou, Richardson, Nute, Wood \& Bishop, 2007). These relationships may result from lipid-dependent mechanisms of flavour and aroma development during cooking, storage or processing (Calkins \& Hodgen, 2007; Elmore \& Mottram, 2009; Mottram, 1998).

The weak negative correlation between tenderness and abnormal beef flavour observed for samples from bulls cooked at $74^{\circ} \mathrm{C}$ and assessed using the UK protocol has not been reported before.

Finally, the PCA allowed us to visually illustrate the relationships between the sensory attributes used in this study. For the UK protocol, the values at the two cooking temperatures were grouped together for each attribute whereas, for the French protocol the values of three attributes (tenderness, juiciness, beef flavour) were grouped together by cooking temperature, reflecting the correlation results presented above. The results illustrate that although tenderness, juiciness and beef flavour attributes may each have an impact on meat sensory quality perception, they are also related and might influence one another in agreement with (Gill et al., 2010). Tenderness and juiciness traits are of great importance when assessing beef meat (Aaslyng et al., 2014). According to Christensen et al. (2012) and Mortensen et al. (2012), a balance between those attributes has to be found to fulfil consumer expectations according to cooking temperature and eating habits.

\section{Conclusion}

The results of this study indicate that irrespective of the sensory protocol, trained panelists from France and the UK expressed the same perceptions for tenderness and juiciness when assessing beef cooked to 55 or $74^{\circ} \mathrm{C}$. Irrespective of animal type and sensory protocol (sensory scale), tenderness and juiciness were higher at $55^{\circ} \mathrm{C}$ than at $74^{\circ} \mathrm{C}$, indicating that cooking at a low end-point temperature, beef texture was scored greater by trained panels of both countries. However, cooking at low end-point temperature produced lower scores for beef flavour and 
higher scores for abnormal flavour by UK panelists but lower abnormal flavour scores, compared to $74^{\circ} \mathrm{C}$, by French panelists.

\section{Acknowledgements}

This work was part of the EU FP6 Integrated Project ProSafeBeef, contract no. FOODCT2006-36241. The INRA reference of the French young bulls is AQ284. Funding by the European Union with respect to animal production and laboratory analyses is greatly acknowledged. We also thank all colleagues involved in the management of the animals in the different countries and those who assisted with data collection, slaughtering of the animals and muscle sampling. A grant from PROFAS B+ program to Dr. Mohammed Gagaoua $(\mathrm{PhD})$ is gratefully acknowledged.

\section{Conflict of interest}

The authors state that there is no conflict of interest. 


\section{References}

Aaslyng, M. D., Meinert, L., Bejerholm, C., \& Warner, R. (2014). SENSORY ASSESSMENT OF MEAT. In M. Dikeman \& C. Devine (Eds.), Encyclopedia of Meat Sciences (Second Edition) (pp. 272-279). Oxford: Academic Press.

Bailey, A. J., \& Light, N. D. (1989). Connective tissue in meat and meat products: Elsevier Applied Science. Barking, England

Bejerholm, C., Tørngren, M. A., \& Aaslyng, M. D. (2014). Cooking of Meat. In M. Dikeman \& C. Devine (Eds.), Encyclopedia of Meat Sciences (Second Edition) (pp. 370-376). Oxford: Academic Press.

Boleman, S. J., Boleman, S. L., Miller, R. K., Taylor, J. F., Cross, H. R., Wheeler, T. L., Koohmaraie, M., Shackelford, S. D., Miller, M. F., West, R. L., Johnson, D. D., \& Savell, J. W. (1997). Consumer evaluation of beef of known categories of tenderness. Journal of Animal Science, 75(6), 1521-1524.

Bowers, J. A., Craig, J. A., Kropf, D. H., \& Tucker, T. J. (1987). Flavor, Color, and Other Characteristics of Beef Longissimus Muscle Heated to Seven Internal Temperatures Between $55^{\circ}$ and $85^{\circ} \mathrm{C}$. Journal of Food Science, 52(3), 533-536.

Bowers, J. A., Dikeman, M. E., Murray, L., \& Stroda, S. L. (2012). Cooked yields, color, tenderness, and sensory traits of beef roasts cooked in an oven with steam generation versus a commercial convection oven to different endpoint temperatures. Meat Science, 92(2), 97-106.

Butler, G., Poste, L. M., Mackie, D. A., \& Jones, A. (1996). Time-intensity as a tool for the measurement of meat tenderness. Food Quality and Preference, 7(3-4), 193-204.

Calkins, C. R., \& Hodgen, J. M. (2007). A fresh look at meat flavor. Meat Science, 77(1), 6380.

Campo, M. M., Nute, G. R., Hughes, S. I., Enser, M., Wood, J. D., \& Richardson, R. I. (2006). Flavour perception of oxidation in beef. Meat Science, 72(2), 303-311.

Christensen, L., Gunvig, A., Torngren, M. A., Aaslyng, M. D., Knochel, S., \& Christensen, M. (2012). Sensory characteristics of meat cooked for prolonged times at low temperature. Meat Science, 90(2), 485-489.

Christensen, M., Purslow, P. P., \& Larsen, L. M. (2000). The effect of cooking temperature on mechanical properties of whole meat, single muscle fibres and perimysial connective tissue. Meat Science, 55(3), 301-307.

Corbin, C. H., O'Quinn, T. G., Garmyn, A. J., Legako, J. F., Hunt, M. R., Dinh, T. T., Rathmann, R. J., Brooks, J. C., \& Miller, M. F. (2015). Sensory evaluation of tender beef strip loin steaks of varying marbling levels and quality treatments. Meat Science, 100, 24-31.

Cross, H. R., Stanfield, M. S., \& Koch, E. J. (1976). Beef Palatability as Affected by Cooking Rate and Final Internal Temperature1. Journal of Animal Science, 43(1), 114-121.

Dransfield, E., Nute, G. R., Roberts, T. A., Boccard, R., Touraille, C., Buchter, L., Casteels, M., Cosentino, E., Hood, D. E., Joseph, R. L., Schon, I., \& Paardekooper, E. J. C. (1984). Beef quality assessed at European research centres. Meat Science, 10(1), 1-20.

Dubost, A., Micol, D., Picard, B., Lethias, C., Andueza, D., Bauchart, D., \& Listrat, A. (2013). Structural and biochemical characteristics of bovine intramuscular connective tissue and beef quality. Meat Science, 95(3), 555-561.

Elmore, J., \& Mottram, D. (2009). Flavour development in meat. Improving the sensory and nutritional quality of fresh meat, 111-146. Woodhead Publishing Ltd, Great Abington, Cambridge. 
Font-i-Furnols, M., \& Guerrero, L. (2014). Consumer preference, behavior and perception about meat and meat products: an overview. Meat Science, 98(3), 361-371.

Gagaoua, M., Micol, D., Hocquette, J. F., Moloney, A., Nuernberg, K., Bauchart, D., Scollan, N., Richardson, R. I., Boudjellal, A., \& Picard, B. (2013). Effect of diets on bovine muscle composition and sensory quality characteristics. In Book of Abstracts of the 64th Annual Meeting of the European Federation for Animal Science, 26-30 of August, (Vol. 19, pp. 567). Nantes, France,: Wagening Academic Publishers.

Gagaoua, M., Micol, D., Richardson, R. I., Hocquette, J. F., Terlouw, E. M. C., Meteau, K., Juin, H., Moloney, A. P., Nuernberg, K., Scollan, N. D., Boudjellal, A., \& Picard, B. (2013). Relationships between overall liking score and sensory meat attributes in different types of beef cattle. In Proceedings of the 59th International Congress of Meat Science and Technology (pp. 4). Izmir, Turkey.

Gagaoua, M., Terlouw, C., Micol, D., Hocquette, J.-F., Moloney, A., Nuernberg, K., Bauchart, D., Boudjellal, A., Scollan, N., Richardson, R. I., \& Picard, B. (2016). Sensory quality of meat from eight different types of cattle in relation with their biochemical characteristics. Journal of Integrative Agriculture, 15(7), 1550-1563.

Gagaoua, M., Terlouw, E. M., Boudjellal, A., \& Picard, B. (2015a). Coherent correlation networks among protein biomarkers of beef tenderness: What they reveal. Journal of Proteomics, 128, 365-374.

Gagaoua M., Terlouw E.M., Micol D., Boudjellal A., Hocquette J.F. \& Picard B. (2015b) Understanding Early Post-Mortem Biochemical Processes Underlying Meat Color and $\mathrm{pH}$ Decline in the Longissimus thoracis Muscle of Young Blond d'Aquitaine Bulls Using Protein Biomarkers. Journal of Agricultural and Food Chemistry 63, 6799-809.

Gill, J. L., Matika, O., Williams, J. L., Worton, H., Wiener, P., \& Bishop, S. C. (2010). Consistency statistics and genetic parameters for taste panel assessed meat quality traits and their relationship with carcass quality traits in a commercial population of Angus-sired beef cattle. Animal, 4(1), 1-8.

Gomes, C. L., Pflanzer, S. B., Cruz, A. G., de Felício, P. E., \& Bolini, H. M. A. (2014). Sensory descriptive profiling and consumer preferences of beef strip loin steaks. Food Research International, 59, 76-84.

Gomes, C. L., Pflanzer, S. B., de Felício, P. E., \& Bolini, H. M. A. (2014). Temporal changes of tenderness and juiciness of beef strip loin steaks. LWT - Food Science and Technology, 59, 629-634.

Grunert, K. G., Bredahl, L., \& Brunsø, K. (2004). Consumer perception of meat quality and implications for product development in the meat sector-a review. Meat Science, 66(2), 259-272.

Hocquette, J. F., Botreau, R., Picard, B., Jacquet, A., Pethick, D. W., \& Scollan, N. D. (2012). Opportunities for predicting and manipulating beef quality. Meat Science, 92(3), 197209.

Huffman, K. L., Miller, M. F., Hoover, L. C., Wu, C. K., Brittin, H. C., \& Ramsey, C. B. (1996). Effect of beef tenderness on consumer satisfaction with steaks consumed in the home and restaurant. Journal of Animal Science, 74(1), 91-97.

Hughes, J. M., Oiseth, S. K., Purslow, P. P., \& Warner, R. D. (2014). A structural approach to understanding the interactions between colour, water-holding capacity and tenderness. Meat Science, 98(3), 520-532.

Hunt, M. R., Garmyn, A. J., O'Quinn, T. G., Corbin, C. H., Legako, J. F., Rathmann, R. J., Brooks, J. C., \& Miller, M. F. (2014). Consumer assessment of beef palatability from four beef muscles from USDA Choice and Select graded carcasses. Meat Science, 98(1), 1-8. 
ISO_8586. (2012). Sensory analysis. General guidelines for the selection, training and monitoring of selected assessors and expert sensory assessors. In (pp. 1-28). International Organization for Standarization, Geneva, Switzerland.

Jenkins, K. H., Vasconcelos, J. T., Hinkle, J. B., Furman, S. A., de Mello, A. S., Jr., Senaratne, L. S., Pokharel, S., \& Calkins, C. R. (2011). Evaluation of performance, carcass characteristics, and sensory attributes of beef from finishing steers fed field peas. Journal of Animal Science, 89(4), 1167-1172.

Jeremiah, L. E., \& Gibson, L. L. (2003). The effects of postmortem product handling and aging time on beef palatability. Food Research International, 36(9-10), 929-941.

Joseph, J. K., Awosanya, B., Adeniran, A. T., \& Otagba, U. M. (1997). The effects of endpoint internal cooking temperatures on the meat quality attributes of selected Nigerian poultry meats. Food Quality and Preference, 8(1), 57-61.

Karamichou, E., Richardson, R. I., Nute, G. R., Wood, J. D., \& Bishop, S. C. (2007). Genetic analyses of sensory characteristics and relationships with fatty acid composition in the meat from Scottish Blackface lambs. Animal, 1(10), 1524-1531.

Lawless, H. T., \& Heymann, H. (2010). Sensory Evaluation of Food: Principles and Practices. Springer Science \& Business Media.

Legrand, I., Hocquette, J. F., Polkinghorne, R. J., \& Pethick, D. W. (2013). Prediction of beef eating quality in France using the Meat Standards Australia system. Animal, 7(3), 524529.

Lorenzen, C. L., Davuluri, V. K., Adhikari, K., \& Grün, I. U. (2005). Effect of End-point Temperature and Degree of Doneness on Sensory and Instrumental Flavor Profile of Beefsteaks. Journal of Food Science, 70(2), S113-S118.

Lorenzen, C. L., Miller, R. K., Taylor, J. F., Neely, T. R., Tatum, J. D., Wise, J. W., Buyck, M. J., Reagan, J. O., \& Savell, J. W. (2003). Beef Customer Satisfaction: Trained sensory panel ratings and Warner-Bratzler shear force values. Journal of Animal Science, 81(1), 143-149.

Macfie, H. J., Bratchell, N., Greenhoff, K., \& Vallis, L. V. (1989). Designs to Balance the Effect of Order of Presentation and First-Order Carry-over Effects in Hall Tests. Journal of Sensory Studies, 4(2), 129-148.

Maher, S. C., Mullen, A. M., Moloney, A. P., Buckley, D. J., \& Kerry, J. P. (2004). Quantifying the extent of variation in the eating quality traits of the M. longissimus dorsi and M. semimembranosus of conventionally processed Irish beef. Meat Science, 66(2), 351-360.

Martens, H., Stabursvik, E., \& Martens, M. (1982). Texture and Colour Changes in Meat during Cooking Related to Thermal Denaturation of Muscle Proteins. Journal of Texture Studies, 13(3), 291-309.

McCormick, R. (2009). Collagen. Applied Muscle Biology and Meat Science. M. Du and RJ McCormick, ed. CRC Press, New York, NY, 129-148.

Miller, M. F., Carr, M. A., Ramsey, C. B., Crockett, K. L., \& Hoover, L. C. (2001). Consumer thresholds for establishing the value of beef tenderness. Journal of Animal Science, 79(12), 3062-3068.

Monson, F., Sanudo, C., \& Sierra, I. (2005). Influence of breed and ageing time on the sensory meat quality and consumer acceptability in intensively reared beef. Meat Science, 71(3), 471-479.

Mortensen, L. M., Frøst, M. B., Skibsted, L. H., \& Risbo, J. (2012). Effect of Time and Temperature on Sensory Properties in Low-Temperature Long-Time Sous-Vide Cooking of Beef. Journal of Culinary Science \& Technology, 10(1), 75-90. 
Mottram, D. S. (1998). Flavour formation in meat and meat products: a review. Food Chemistry, 62(4), 415-424.

O'Quinn, T. G., Brooks, J. C., Polkinghorne, R. J., Garmyn, A. J., Johnson, B. J., Starkey, J. D., Rathmann, R. J., \& Miller, M. F. (2012). Consumer assessment of beef strip loin steaks of varying fat levels. Journal of Animal Science, 90(2), 626-634.

Obuz, E., \& Dikeman, M. E. (2003). Effects of cooking beef muscles from frozen or thawed states on cooking traits and palatability. Meat Science, 65(3), 993-997.

Oliver, M. A., Nute, G. R., Font, I. F. M., San Julian, R., Campo, M. M., Sanudo, C., Caneque, V., Guerrero, L., Alvarez, I., Diaz, M. T., Branscheid, W., Wicke, M., \& Montossi, F. (2006). Eating quality of beef, from different production systems, assessed by German, Spanish and British consumers. Meat Science, 74(3), 435-442.

Otremba, M. M., Dikeman, M. E., Milliken, G. A., Stroda, S. L., Chambers Iv, E., \& Chambers, D. (2000). Interrelationships between descriptive texture profile sensory panel and descriptive attribute sensory panel evaluations of beef Longissimus and Semitendinosus muscles. Meat Science, 54(4), 325-332.

Pannier, L., Gardner, G. E., Pearce, K. L., McDonagh, M., Ball, A. J., Jacob, R. H., \& Pethick, D. W. (2014). Associations of sire estimated breeding values and objective meat quality measurements with sensory scores in Australian lamb. Meat Science, 96(2), 1076-1087.

Pegg, R. B., \& Shahidi, F. (2004). HEAT EFFECTS ON MEAT | Flavour Development A2 Jensen, Werner Klinth. In Encyclopedia of Meat Sciences (pp. 570-578). Oxford: Elsevier.

Platter, W. J., Tatum, J. D., Belk, K. E., Koontz, S. R., Chapman, P. L., \& Smith, G. C. (2005). Effects of marbling and shear force on consumers' willingness to pay for beef strip loin steaks. Journal of Animal Science, 83(4), 890-899.

Purslow, P. P. (2014). New developments on the role of intramuscular connective tissue in meat toughness. Annual Reviews of Food Science and Technology, 5, 133-153.

Sanudo, C., Nute, G. R., Campo, M. M., Maria, G., Baker, A., Sierra, I., Enser, M. E., \& Wood, J. D. (1998). Assessment of commercial lamb meat quality by British and Spanish taste panels. Meat Science, 48, 91-100.

Savell, J. W., Cross, H. R., Francis, J. J., Wise, J. W., Hale, D. S., Wilkes, D. L., \& Smith, G. C. (1989). National Consumer Retail Beef Study: Interaction of Trim Level, Price and Grade on Consumer Acceptance of Beef Steaks and Roasts. Journal of Food Quality, 12(4), 251-274.

Savell, J. W., Lorenzen, C. L., Neely, T. R., Miller, R. K., Tatum, J. D., Wise, J. W., Taylor, J. F., Buyck, M. J., \& Reagan, J. O. (1999). Beef customer satisfaction: cooking method and degree of doneness effects on the top sirloin steak. Journal of Animal Science, 77(3), 645-652.

Shackelford, S. D., Wheeler, T. L., \& Koohmaraie, M. (1995). Relationship between shear force and trained sensory panel tenderness ratings of 10 major muscles from Bos indicus and Bos taurus cattle. Journal of Animal Science, 73(11), 3333-3340.

Tornberg, E. (2005). Effects of heat on meat proteins - Implications on structure and quality of meat products. Meat Science, 70(3), 493-508.

Verbeke, W., Van Wezemael, L., de Barcellos, M. D., Kugler, J. O., Hocquette, J. F., Ueland, O., \& Grunert, K. G. (2010). European beef consumers' interest in a beef eatingquality guarantee Insights from a qualitative study in four EU countries. Appetite, 54(2), 289-296.

Wood, J. D., Nute, G. R., Fursey, G. A. J., \& Cuthbertson, A. (1995). The effect of cooking conditions on the eating quality of pork. Meat Science, 40(2), 127-135. 
Wulf, D. M., Morgan, J. B., Tatum, J. D., \& Smith, G. C. (1996). Effects of animal age, marbling score, calpastatin activity, subprimal cut, calcium injection, and degree of doneness on the palatability of steaks from limousin steers. Journal of Animal Science, 74(3), 569-576.

Young, O. A., Reid, D. H., \& Scales, G. H. (1993). Effect of breed and ultimate pH on the odour and flavour of sheep meat. New Zealand Journal of Agricultural Research, 36(3), 363-370.

Zimoch, J., \& Gullett, E. A. (1997). Temporal aspects of perception of juiciness and tenderness of beef. Food Quality and Preference, 8(3), 203-211. 


\section{Table 1}

Numbers of Longissimus thoracis beef samples assessed using sensory protocols in the United Kingdom and in France at two endpoint cooking temperatures $\left(55\right.$ and $\left.74^{\circ} \mathrm{C}\right)$.

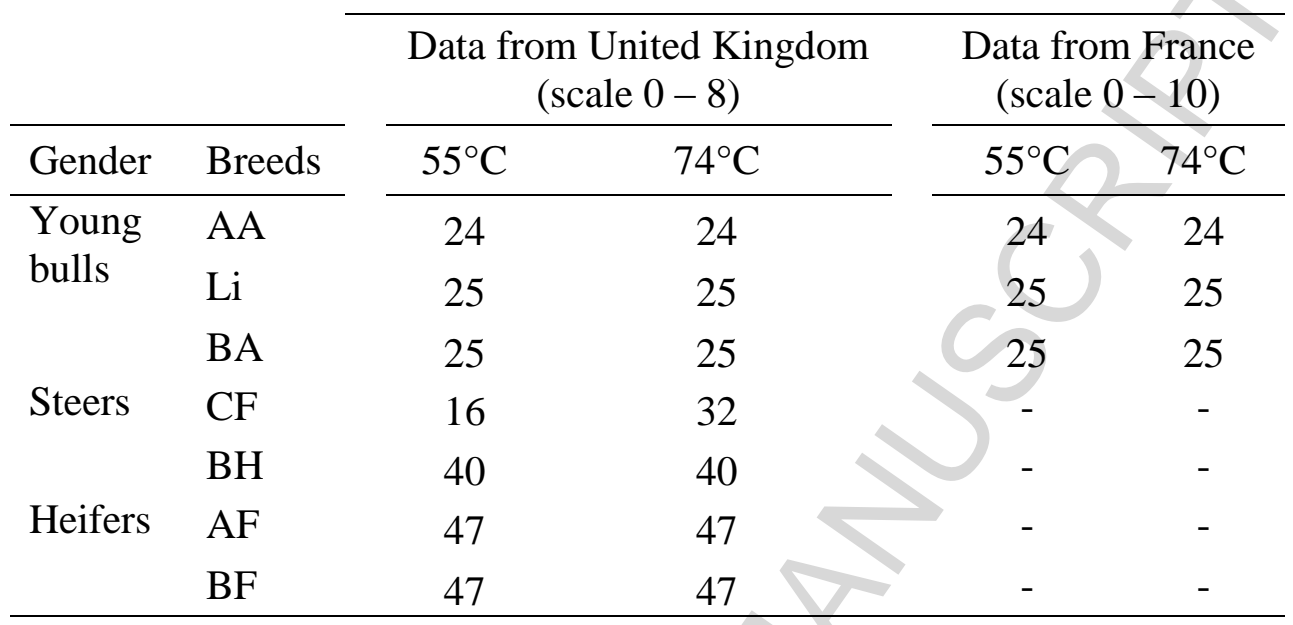

Abbreviations: young bulls (AA: Aberdeen Angus, Li: Limousin, BA: Blond d'Aquitaine); Heifers (AF: Aberdeen Angus x Friesian, BF: Belgian-Blue x Friesian), and Steers (BH: Belgian-Blue x Holstein, CF: Charolais $\mathrm{x}$ Friesian). Beef sample cells in the table indicated by (-) were not evaluated.

\section{Table 2}

Definitions of the eating quality descriptors used in the sensory evaluation of beef meat with trained sensory panels ${ }^{1}$

\begin{tabular}{ll}
\hline Attributes & Definition \\
\hline Global tenderness & $\begin{array}{l}\text { Ease of chewing the sample between teeth: from } \\
\text { extremely tough }(0) \text { to extremely tender }(8 \text { or } 10)\end{array}$ \\
Juiciness & $\begin{array}{l}\text { Amount of moisture released in the mouth: not juicy }(0) \\
\text { to extremely juicy }(8 \text { or } 10)\end{array}$ \\
Beef flavour & $\begin{array}{l}\text { Flavour associated with cooked beef: extremely weak } \\
\text { beef flavour }(0) \text { to extremely strong beef flavour }(8 \text { or } 10) \\
\text { Abnormal beef flavour }\end{array}$ \\
$\begin{array}{l}\text { Abnormal flavour not found in cooked beef: none }(0) \text { to } \\
\text { strong off-flavour }(8 \text { or } 10)\end{array}$ \\
\hline
\end{tabular}

${ }^{1}$ For the UK protocol, a 0-8 point category scale was used, and for the French protocol, a 0-10 unstructured scale was used. 


\section{Table 3}

Effect of cooking temperature on the sensory attributes of beef from young bulls, steers and heifers assessed by the United Kingdom panel at two end-point cooking temperatures $\left(55 \text { and } 74^{\circ} \mathrm{C}\right)^{\mathrm{a}}$

\begin{tabular}{|c|c|c|c|c|}
\hline \multirow[b]{2}{*}{ Attributes ${ }^{b}$} & \multicolumn{2}{|c|}{ Cooking temperature } & \multirow{2}{*}{$S E M^{c}$} & \multirow{2}{*}{$P$-value ${ }^{d}$} \\
\hline & $55^{\circ} \mathrm{C}$ & $74^{\circ} \mathrm{C}$ & & \\
\hline \multicolumn{5}{|c|}{ Young bulls } \\
\hline Tenderness & 3.9 & 3.0 & 0.09 & $* * *$ \\
\hline Juiciness & 5.2 & 3.7 & 0.08 & $* * *$ \\
\hline Beef flavour & 2.1 & 2.6 & 00 & $* * *$ \\
\hline Abnormal flavour & 2.4 & 2.0 & 0.06 & $* * *$ \\
\hline Tenderness & 5.1 & .6 & 0.06 & $* * *$ \\
\hline Juiciness & 5.7 & & 0.07 & $* * *$ \\
\hline Beef flavour & & 4.9 & 0.05 & $* * *$ \\
\hline Abnormal flavour & & 2.7 & 0.04 & $* * *$ \\
\hline Tenderness & 5.2 & 4.6 & 0.05 & $* * *$ \\
\hline Juiciness & 5.9 & 5.3 & 0.04 & $* * *$ \\
\hline Beef flavour & 4.1 & 4.4 & 0.03 & $* * *$ \\
\hline Abnormal flavour & 2.4 & 2.1 & 0.03 & $* * *$ \\
\hline
\end{tabular}

${ }^{a}$ Data used correspond to young bulls, steers and heifers (as in Table 1) for beef samples assessed by panelists using the United Kingdom protocol at 55 and $74^{\circ} \mathrm{C}$.

${ }^{\mathrm{b}}$ LSmeans of each attribute (scored on a 0-8 point category scale, as described in Table 2).

${ }^{\mathrm{c}}$ Standard error of mean

${ }^{\mathrm{d}}$ Significance level: $* * * P<0.001$. 


\section{Table 4}

Effect of cooking temperature on the sensory attributes of beef from young bulls assessed by the French panel at two end-point cooking temperatures $\left(55 \text { and } 74^{\circ} \mathrm{C}\right)^{a}$

\begin{tabular}{|c|c|c|c|c|}
\hline \multirow[b]{2}{*}{ Attributes ${ }^{\mathrm{b}}$} & \multicolumn{2}{|c|}{ Cooking temperature } & \multirow{2}{*}{$S E M^{c}$} & \multirow{2}{*}{ P-value } \\
\hline & $55^{\circ} \mathrm{C}$ & $74^{\circ} \mathrm{C}$ & & \\
\hline Tenderness & 4.9 & 4.3 & 0.07 & \\
\hline Juiciness & 4.7 & 3.6 & 0.06 & \\
\hline Beef flavour & 4.0 & 3.9 & & $\mathrm{~ns}$ \\
\hline Abnormal flavour & 2.3 & 3.1 & 0.05 & $* * *$ \\
\hline
\end{tabular}

${ }^{\text {a }}$ Data used correspond to young bulls only (as in Table 1) for beef samples assessed by panelists from France at 55 and $74^{\circ} \mathrm{C}$.

${ }^{\mathrm{b}}$ LSmeans of each attribute (scored on a 0-10 unstructured scale, as described in Table 2).

${ }^{\mathrm{c}}$ Standard error of mean

${ }^{\mathrm{d}}$ Significance level: ns: not significant; $* * * P<0.001$. 


\section{Table 5}

Pearson correlation coefficients estimated from the pooled within-animal type Z-scores of all animal types for beef sensory scores of United Kingdom panelists at end-point cooking temperatures of 55 and $74^{\circ} \mathrm{C}$.

\begin{tabular}{lll}
\hline Tenderness & Juiciness & Beef flavor \\
\hline
\end{tabular}

\section{$55^{\circ} \mathrm{C}$}

\begin{tabular}{|c|c|c|c|}
\hline Juiciness & $0.33 * * *$ & & \\
\hline Beef flavour & $0.15^{*}$ & -0.05 & \\
\hline Abnormal beef flavour & $-0.15^{*}$ & 0.10 & $-0.62 * * *$ \\
\hline Juiciness & $0.42 * * *$ & & \\
\hline Beef flavour & $0.29 * *$ & $0.18^{*}$ & \\
\hline Abnormal beef flavour & -0.10 & 0.04 & $-0.56^{* * * *}$ \\
\hline
\end{tabular}

Significance: $* P<0.05 ; * * P<0.01 ; * * * P<0.001$.

\section{Table 6}

Pearson correlation coefficients estimated from the pooled within-animal type Z-scores of young bulls for beef sensory scores of French panelists at end-point cooking temperatures of 55 and $74^{\circ} \mathrm{C}$.

\begin{tabular}{ccc}
\hline Tenderness & Juiciness & Beef flavor \\
\hline $\mathbf{5 5}^{\circ} \mathbf{C}$ &
\end{tabular}

\begin{tabular}{llcl}
\hline Juiciness & $\mathbf{0 . 4 0} * * *$ & & \\
Beef flavour & $\mathbf{0 . 4 0 * *}$ & $\mathbf{0 . 2 3}^{*}$ & 0.19 \\
Abnormal beef flavour & -0.08 & -0.20 & \\
\hline & & $\mathbf{7 4}^{\circ} \mathbf{C}$ & \\
\hline Juiciness & $\mathbf{0 . 6 4} * * *$ & & \\
Beef flavour & $\mathbf{0 . 5 0 * * *}$ & $\mathbf{0 . 4 9} * * *$ & -0.02 \\
Abnormal beef flavour & 0.03 & $\mathbf{- 0 . 2 6}$ \\
\hline
\end{tabular}

Significance: $* P<0.05 ; * * P<0.01 ; * * * P<0.001$. 


\section{Figure captions}

\section{Figure 1}

Principal components analysis performed on the pooled within-animal type Z-scores of all animal types for samples evaluated by panelists from the United Kingdom at $55^{\circ} \mathrm{C}(\boldsymbol{\Delta})$ and $74^{\circ} \mathrm{C}(\Delta)$ as indicated in Table 1. The overall Kaiser's Measure of Sampling Adequacy was 0.72. Abbreviations: GT: global tenderness; JUIC: juiciness; BF: beef flavour; ABF: abnormal beef flavour.

\section{Figure 2}

Principal components analysis performed on the pooled within-animal type Z-scores for samples from young bulls evaluated by panelists from France at $55^{\circ} \mathrm{C}(\bullet)$ and $74^{\circ} \mathrm{C}(\mathrm{O})$ as indicated in Table 1. The overall MSA was 0.73. Abbreviations: GT: global tenderness; JUIC: juiciness; BF: beef flavour; ABF: abnormal beef flavour. 


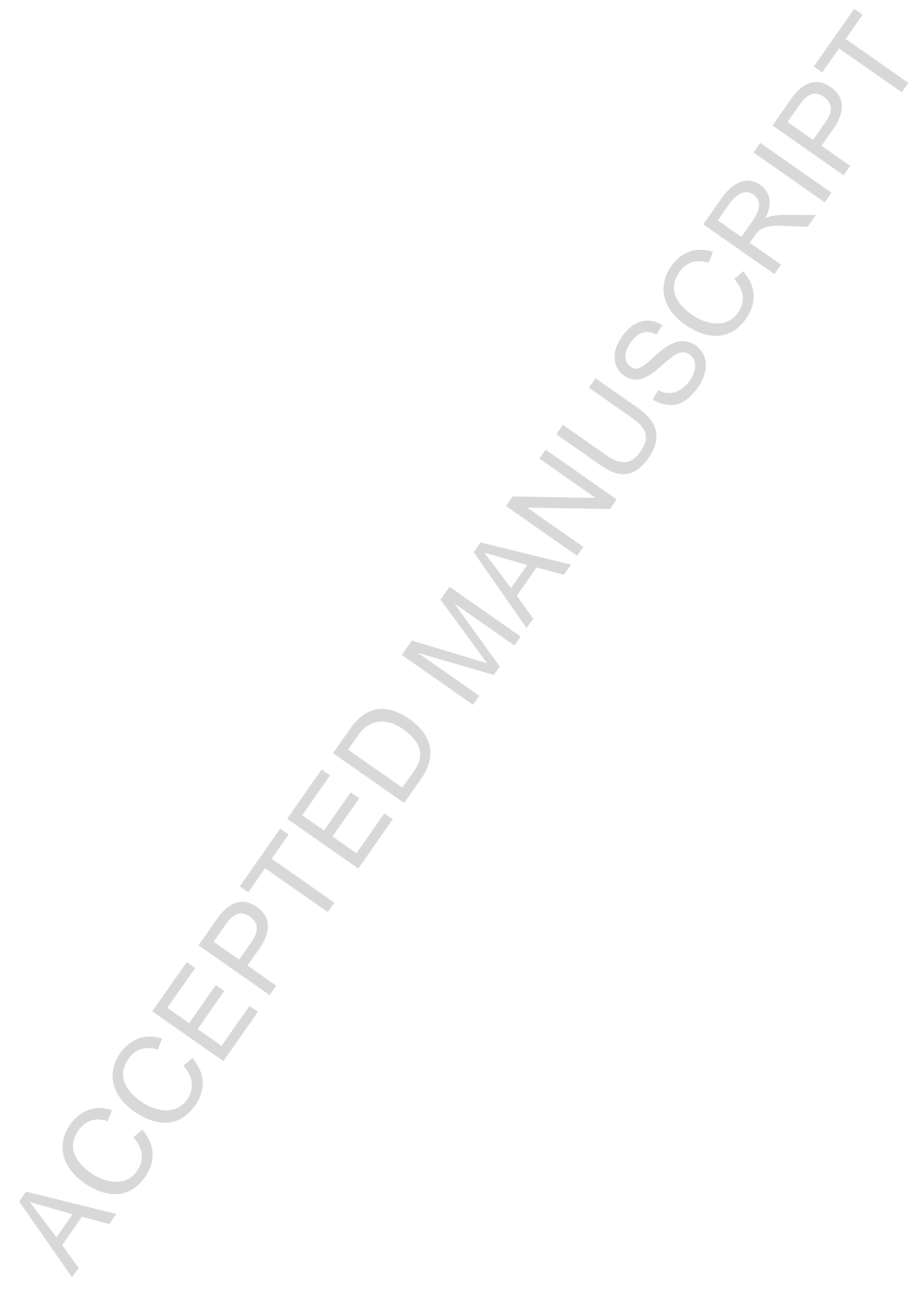




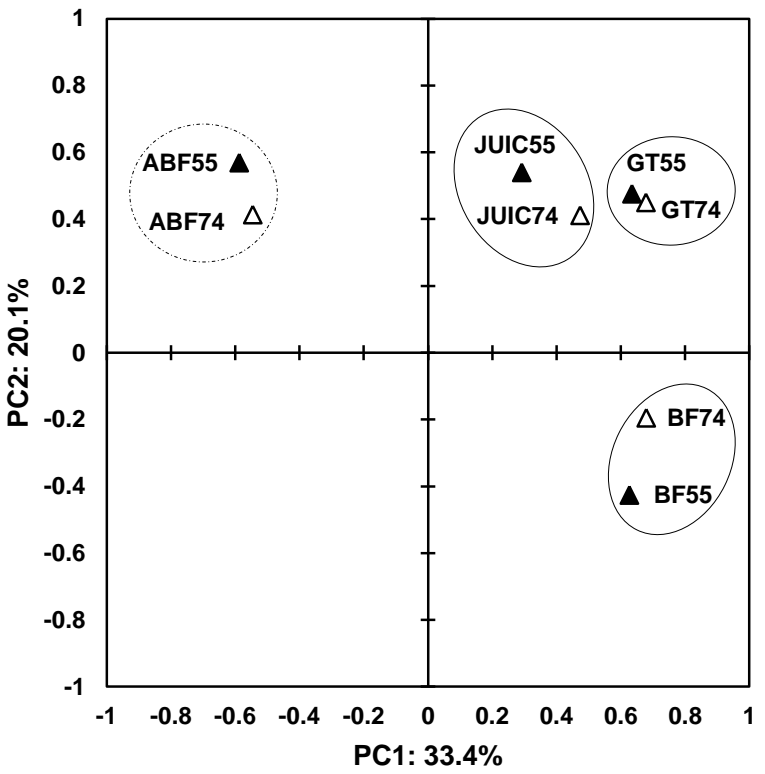

Figure 1

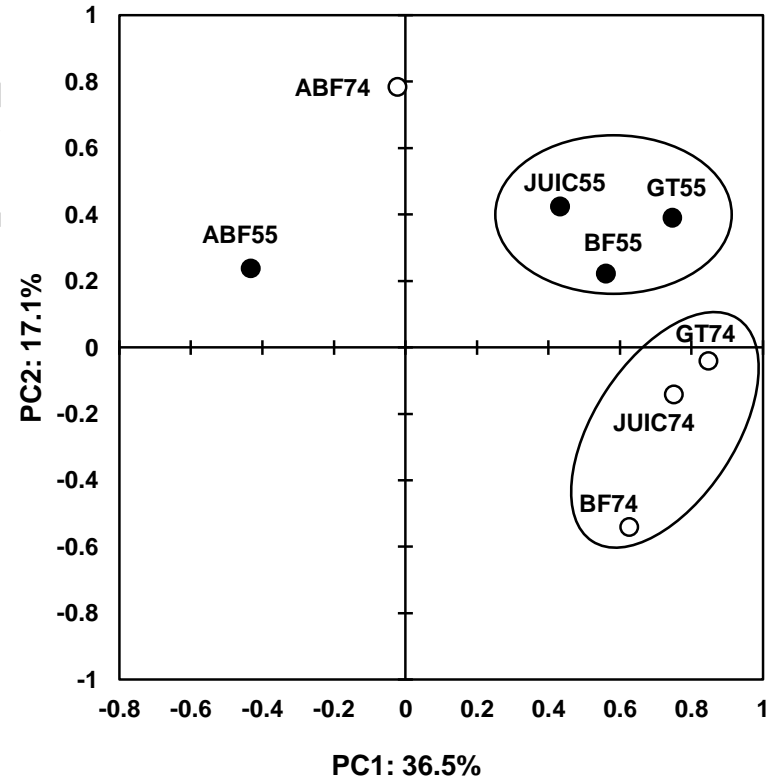

Figure 2 


\section{Highlights}

- Tenderness and juiciness scores of beef meat from heifers, steers and young bulls were greater at $55^{\circ} \mathrm{C}$ than $74^{\circ} \mathrm{C}$.

- With the UK panel, beef flavour was greater and abnormal beef flavour lower at $74^{\circ} \mathrm{C}$ than at $55^{\circ} \mathrm{C}$.

- With the French panel, abnormal beef flavour was greater at $74^{\circ} \mathrm{C}$ than at $55^{\circ} \mathrm{C}$. 